\title{
Article \\ Effects of Zn Addition on the Microstructure and Mechanical Properties of As-Extruded Mg-2Al-0.5Ca Alloy
}

\author{
Ming Yuan ${ }^{1,2,3, *}$, Chao He ${ }^{1}$, Yan Song ${ }^{1}$, Bin Lei ${ }^{1}$, Xiaoying Qian ${ }^{1}$, Zhihua Dong ${ }^{1,2}$, Jun Zhao ${ }^{4}$, Huabao Yang ${ }^{5}$, \\ Yanfu Chai ${ }^{5}$, Bin Jiang ${ }^{1,2, *}$ and Fusheng Pan ${ }^{1,2}$
}

1 State Key Laboratory of Mechanical Transmissions, College of Materials Science and Engineering, Chongqing University, Chongqing 400044, China; 20170902015t@cqu.edu.cn (C.H.); 20170901042@cqu.edu.cn (Y.S.); 20180901018@cqu.edu.cn (B.L.); 20200901068@cqu.edu.cn (X.Q.); dzhihua@cqu.edu.cn (Z.D.); fspan@cqu.edu.cn (F.P.)

2 National Engineering Research Center for Magnesium Alloys, Chongqing University, Chongqing 400044, China

3 School of Chemistry and Materials Science, Hubei Engineering University, Xiaogan 432000, China

4 School of Mechanical and Electrical Engineering, Hunan City University, Yiyang 413002, China; 20160901005@cqu.edu.cn

5 School of Mechanical and Electrical Engineering, Shaoxing University, Shaoxing 312000, China; 2021000100@usx.edu.cn (H.Y.); 2021000043@usx.edu.cn (Y.C.)

* Correspondence: yuanming@cqu.edu.cn (M.Y.); jiangbinrong@cqu.edu.cn (B.J.)

Citation: Yuan, M.; He, C.; Song, Y.; Lei, B.; Qian, X.; Dong, Z.; Zhao, J.; Yang, H.; Chai, Y.; Jiang, B.; et al. Effects of $\mathrm{Zn}$ Addition on the Microstructure and Mechanical Properties of As-Extruded Mg-2Al-0.5Ca Alloy. Metals 2022, 12, 221. https://doi.org/10.3390/ met12020221

Received: 19 December 2021

Accepted: 20 January 2022

Published: 25 January 2022

Publisher's Note: MDPI stays neutral with regard to jurisdictional claims in published maps and institutional affiliations.

Copyright: (C) 2022 by the authors. Licensee MDPI, Basel, Switzerland. This article is an open access article distributed under the terms and conditions of the Creative Commons Attribution (CC BY) license (https:// creativecommons.org/licenses/by/ $4.0 /)$.

\begin{abstract}
The effects of $\mathrm{Zn}$ addition on the microstructure and tensile properties of as-extruded Mg-2Al-0.5Ca-xZn ( $x=0,0.3,0.6,0.9$ wt.\%) alloys were investigated in this work. The results showed that the extruded sheets exhibited a completely dynamically recrystallized microstructure, the grain size was refined, and texture weakening was achieved with $\mathrm{Zn}$ addition because of the segregation of $\mathrm{Zn}$ atoms on grain boundaries, which suppresses the growth of dynamic recrystallized grains. The addition of $0.6 \mathrm{wt} . \% \mathrm{Zn}$ improved both the tensile strength and ductility of the as-extruded Mg-2Al$0.5 \mathrm{Ca}$ alloy. The as-extruded $\mathrm{Mg}-2 \mathrm{Al}-0.5 \mathrm{Ca}-0.6 \mathrm{Zn}$ alloy showed a $0.2 \%$ proof stress of $145 \mathrm{MPa}$, an ultimate tensile strength of $317 \mathrm{MPa}$, and an elongation of $30.0 \%$ along the extruded direction. The simultaneous improvement of strength and ductility was mainly due to the fine and homogeneous grain microstructure and the weakened extrude direction (ED)-tilted texture. The as-extruded $\mathrm{Mg}$ 2Al-0.5Ca-0.6Zn alloy showed little in-plane anisotropic tensile properties, with a $0.2 \%$ proof stress, ultimate tensile strength, and elongation in the $45^{\circ}$ direction of $148 \mathrm{MPa}, 299 \mathrm{MPa}$, and $25.0 \%$, and those in the transverse direction of $148 \mathrm{MPa}, 269 \mathrm{MPa}$, and $16.8 \%$, respectively.
\end{abstract}

Keywords: Mg-2Al-0.5Ca alloy; extrusion; microstructure; dynamic recrystallization; texture

\section{Introduction}

Magnesium $(\mathrm{Mg})$ alloy is the lightest commercial structural material for engineering applications such as transportation, aerospace, and 3C (consumer electronics, computer, and communication) industries [1-5]. Conventional wrought alloy, e.g., AZ31, usually forms a strong basal texture with the (0002) basal poles parallel to the normal direction (ND) after the hot extrusion or rolling process. This texture characterization limits the secondary forming processes such as sheet pressing. Therefore, modifying the texture features and improving the mechanical properties of $\mathrm{Mg}$ alloys have attracted many researchers to the $\mathrm{Mg}$ alloys research field over the past decades.

Alloying is a useful method to modify Mg alloys' texture, and it is widely reported that $\mathrm{Mg}$ alloys containing rare earth (RE) elements show a weak basal texture because of the RE elements' solute segregation and drag effect on grain boundaries [6-10]. Although the addition of RE elements could improve the mechanical properties of the Mg alloys, the high cost of REs is the limitation for its wide application. Ca is an inexpensive alloying element compared to RE elements, and it has been reported that $\mathrm{Mg}$ alloys with Ca can exhibit 
an ED-split texture component similar to RE-containing alloys after the hot deformation process [11-13]. In the past decade, many researchers have investigated the microstructures and mechanical properties of the wrought Mg-Al-Ca-based alloys [14-18]. Sandlobes et al. developed a rolled Mg-1Al-0.1Ca (wt.\%) alloy sheet, which showed superior mechanical properties with an ultimate tensile strength of $\sim 220 \mathrm{MPa}$ and elongation of about $20 \%$ [19]. The study showed that $\mathrm{Al}$ and $\mathrm{Ca}$ additions alter the deformation mechanism, activate the pyramidal slip activity, in addition to the basal $<a>$ slip. Kim et al. revealed that 0.5 wt.\% Ca addition in AZ31 alloy can weaken the basal texture and enhance the activity of nonbasal slip systems, contributing to the enhanced mechanical properties [20]. Ding et al. also revealed that the Ca element can weaken the texture and improve the ductility of rolled Mg alloy sheets [21]. Kamado et al. developed a wrought Mg-1.3Al-0.3Ca-0.4Mn (wt.\%) alloy, which showed an ultimate tensile strength of $306 \mathrm{MPa}$ and an elongation of $20 \%$ after age-hardening [14]. Concerning the low cost and low-alloyed development of $\mathrm{Mg}$ alloys, we calculated the composition of the Mg-2Al-0.5Ca-based alloys to avoid the $\mathrm{Mg}_{17} \mathrm{Al}_{12}$ precipitates while retaining the $\mathrm{Al}_{2} \mathrm{Ca}$ phase. Furthermore, $\mathrm{Zn}$ is also a promising element to influence the texture evolution and mechanical properties of $\mathrm{Mg}$ alloys [22-25]. Zhao et al. [26] reported that the intensity of the basal texture weakened as the $\mathrm{Zn}$ content increased from 1 to $4 \mathrm{wt}$ \% in the as-extruded $\mathrm{Mg}-\mathrm{XZn}$ alloys. Nakata et al. [27] discovered that adding $1 \mathrm{wt} . \% \mathrm{Zn}$ into the $\mathrm{Mg}-8 \mathrm{Al}-1 \mathrm{Ca}-0.3 \mathrm{Mn}$ alloy can refine the grain size and improve its mechanical properties. However, in the Mg-Al-Zn-based alloys, when a $\mathrm{Zn}$ content over $1 \mathrm{wt}$ \% would make the weldability of the Mg alloy worse [28], the $\mathrm{Zn}$ content should be limited to within $1 \mathrm{wt}$ \%. As we know, extrusion is a common thermo-mechanical process to improve the performance of $\mathrm{Mg}$ alloys [29-32]. Based on the aforementioned information, in this work, we developed a novel extruded $\mathrm{Mg}-2 \mathrm{Al}-0.5 \mathrm{Ca}$ (AX21) alloy with different $\mathrm{Zn}$ contents $(0,0.3,0.6$, and $0.9 \mathrm{wt}$.\%) to obtain comprehensive performance with high ductility and strength. The purpose was to reveal the influence of $\mathrm{Zn}$ addition on the microstructure evolution and tensile properties of the as-extruded $\mathrm{Mg}$-2Al-0.5Ca alloy, and hopefully provide a guide to develop new low-cost wrought $\mathrm{Mg}$ alloys with medium strength and high ductility. Compared to commercial AZ31 alloy, the Mg-2Al-0.5Ca-based alloy has a lower content of alloying additions and low-density Ca. It will have more advantages in applications if the $\mathrm{Mg}-2 \mathrm{Al}-0.5 \mathrm{Ca}-\mathrm{based}$ alloy has superior mechanical properties.

\section{Materials and Experimental Procedure}

Four experimental Mg-2Al-0.5Ca-xZn $(x=0,0.3,0.6,0.9$, all in wt.\%) ingots were prepared from high-purity $\mathrm{Mg}(99.95 \mathrm{wt} \%$ ), pure $\mathrm{Al}(99.9 \%)$, pure $\mathrm{Zn}(99.99 \mathrm{wt} \%$ ), and Mg-20 wt.\% Ca master alloys. The raw materials were melted in a steel crucible under a $\mathrm{CO}_{2}+1 \mathrm{vol}^{\circ} \mathrm{SSF}_{6}$ atmosphere at $720{ }^{\circ} \mathrm{C}$, and the melts were maintained at $\sim 720{ }^{\circ} \mathrm{C}$ for $15 \mathrm{~min}$ and then cast into a preheated cylindrical mold at $250{ }^{\circ} \mathrm{C}$. The actual chemical compositions of the experimental alloys were measured by X-ray fluorescence spectrometry (XRF-1800 Shimadzu, Japan), and the results are shown in Table 1. The cast ingots were homogenized at $400{ }^{\circ} \mathrm{C}$ for $24 \mathrm{~h}$ and water-quenched. Afterward, the ingots were extruded at $300{ }^{\circ} \mathrm{C}$ with a ram speed of $1 \mathrm{~mm} / \mathrm{s}$ and an extrusion ratio is 32 . Consequently, sheets $56 \mathrm{~mm}$ in width and $5 \mathrm{~mm}$ in thickness were obtained.

Table 1. The nominal compositions of the experimental alloys.

\begin{tabular}{ccccc}
\hline \multirow{2}{*}{ Nominal Composition } & \multicolumn{4}{c}{ Measured Composition (wt.\%) } \\
\cline { 2 - 5 } & Al & Ca & Zn & Mg \\
\hline Alloy 1: Mg-2Al-0.5Ca & 2.29 & 0.64 & - & Bal. \\
Alloy 2: Mg-2Al-0.5Ca-0.3Zn & 2.21 & 0.51 & 0.28 & Bal. \\
Alloy 3: Mg-2Al-0.5Ca-0.6Zn & 2.35 & 0.49 & 0.56 & Bal. \\
Alloy 4: Mg-2Al-0.5Ca-0.9Zn & 2.22 & 0.53 & 0.91 & Bal. \\
\hline
\end{tabular}


The tensile tests were carried out on a uniaxial test machine (CMT6305-300 kN, SUNSTEST, Shenzhen, China) with a cross-head speed of $1.5 \mathrm{~mm} / \mathrm{min}$ (strain rate is $0.002 \mathrm{~s}^{-1}$ ) at room temperature (RT) according to ASTM standard E8-2004. Tensile samples had a gauge length of $12 \mathrm{~mm}$ and cross-sectional areas of $6 \mathrm{~mm} \times 5 \mathrm{~mm}$. To ensure reproducibility, three tensile samples were repeated, and the results were presented as the average.

Microstructure observation was performed using an optical microscope (OM, ZEISS Axiovert 40 MAT, Jena, Germany) and a scanning electron microscope (SEM, JEOL JSM7800F, Tokyo, Japan). For the electron backscatter diffraction (EBSD) observation, the samples were mechanically ground and polished in the AC2 solution at $-25{ }^{\circ} \mathrm{C}$ with a potential of $20 \mathrm{~V}$ for $90 \mathrm{~s}$. Phase identification was performed on a D/Max2500 X-ray diffraction instrument(Rigaku, Toyko, Japan) at $36 \mathrm{kV}$, and the scan speed was $4^{\circ} / \mathrm{min}$. The transmission electron microscopy (TEM) observations were performed on a Talos F200X G2 microscope (Thermo Fisher Scientific Inc., Waltham, MA, USA) at an accelerating voltage of $200 \mathrm{kV}$.

\section{Results}

\subsection{Microstructures of As-Cast Alloy}

Figure 1 shows the SEM images of the as-cast samples of $\mathrm{Mg}-2 \mathrm{Al}-0.5 \mathrm{Ca}-\mathrm{xZn}(\mathrm{x}=0,0.3$, $0.6,0.9$ wt. $\%$ ) alloys. It can be seen that the second phases are distributed in all the alloy samples. The second phases, which are pointed out by cross marks A-D in Figure 1, were examined by EDS, and the corresponding EDS analysis results are presented in Table 2, which indicates that the stoichiometry of the second phase is near $\mathrm{Al}_{2} \mathrm{Ca}$. Figure 2 shows the $\mathrm{X}$-ray diffraction spectra of the as-cast alloys, and it illustrates that the as-cast alloys are composed of $\alpha-\mathrm{Mg}$ and $\mathrm{Al}_{2} \mathrm{Ca}$ phases. The $\mathrm{Mg}-2 \mathrm{Al}-\mathrm{xCa}(\mathrm{x}, 0-1 \mathrm{wt} . \%)$ phase diagram is shown in Figure 3, which was calculated by Pandat software(CompuTherm, Middleton, WI, USA). With the fixed Al content of 2 wt. $\%$ and varied Ca (0-1 wt.\%) content, it was found that $\mathrm{Al}_{2} \mathrm{Ca}$ phases are the main precipitates in the $\mathrm{Mg}-2 \mathrm{Al}-0.5 \mathrm{Ca}$ alloy.

\subsection{Microstructures of the As-Extruded Alloy}

The OM images of the as-extruded sheet samples in the ED-TD plane are shown in Figure 4, where ED is the extrusion direction and TD is the transverse direction. It can be seen that all the as-extruded sheets show complete equiaxed DRXed grains. The average grain size of as-extruded Zn-contained alloys is refined compared to Zn-free alloys. In addition, many second phases are observed in the SEM images (seen in Figure 5), where these second phases distribute along the extrusion direction of the as-extruded samples. According to the EDS results (Table 3) and XRD analysis (Figure 6), these second phases are $\mathrm{Al}_{2} \mathrm{Ca}$, which are the intermetallic phases and are broken up into particles during the extrusion process.

\section{(a)}

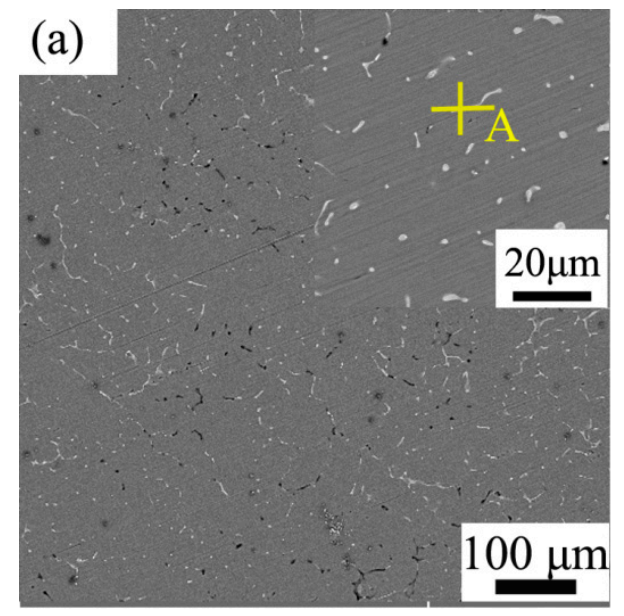

Figure 1. Cont.

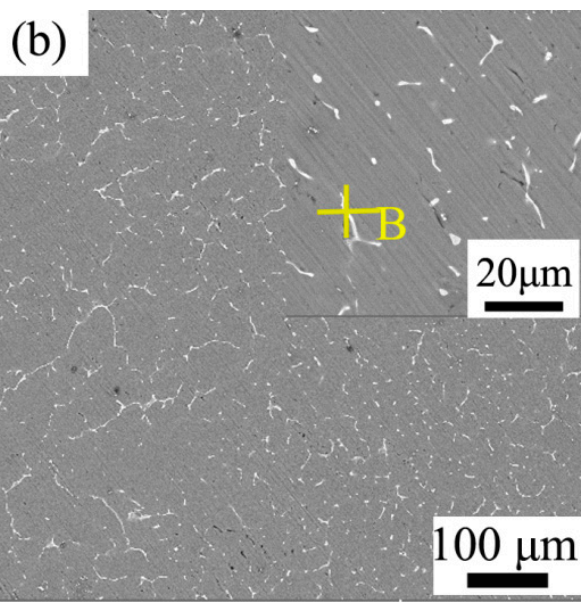




\section{(c)}

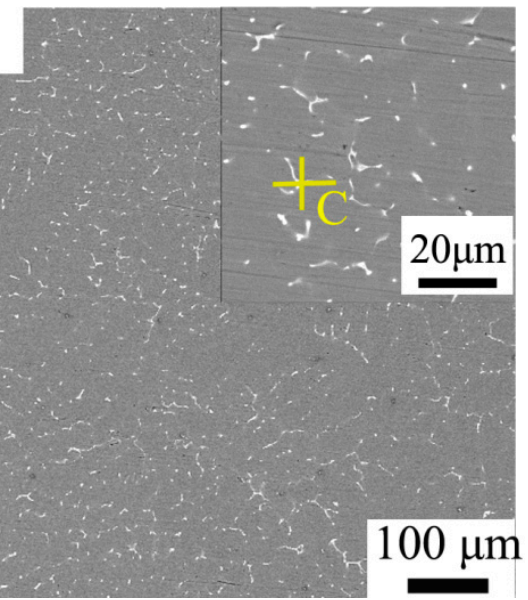

(d)

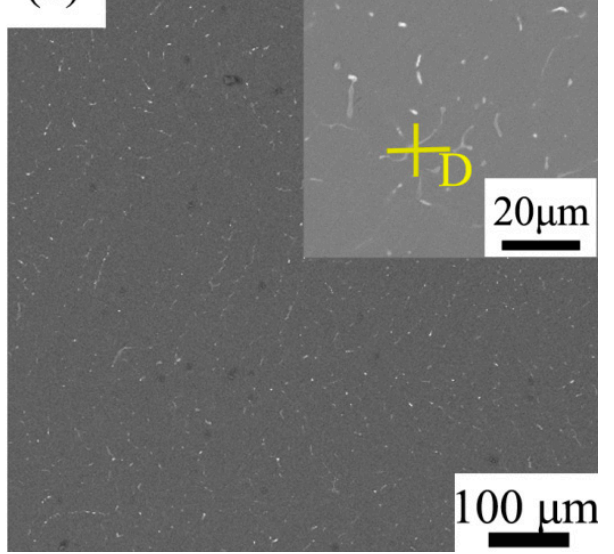

Figure 1. SEM images of the as-cast alloys: (a) alloy 1, (b) alloy 2, (c) alloy 3, and (d) alloy 4. A-D are point EDS of the second phases.

Table 2. EDS analysis of the second phases in as-cast Mg-2Al-0.5Ca-xZn alloys (at \%).

\begin{tabular}{ccccc}
\hline Position & Mg & Ca & Al & Possible Phases \\
\hline A & 76.12 & 7.72 & 16.16 & $\mathrm{Al}_{2} \mathrm{Ca}$ \\
B & 66.53 & 9.55 & 23.92 & $\mathrm{Al}_{2} \mathrm{Ca}$ \\
C & 70.03 & 9.58 & 20.38 & $\mathrm{Al}_{2} \mathrm{Ca}$ \\
D & 49.55 & 15.49 & 34.96 & $\mathrm{Al}_{2} \mathrm{Ca}$ \\
\hline
\end{tabular}

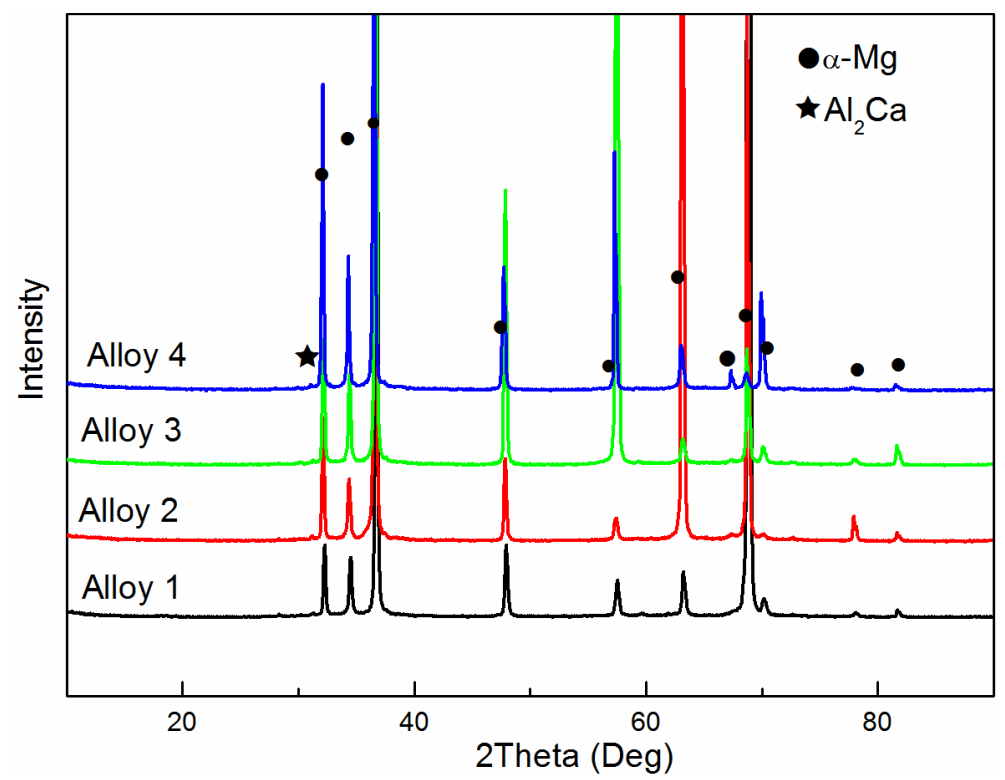

Figure 2. X-ray diffraction spectra of the as-cast alloys. 


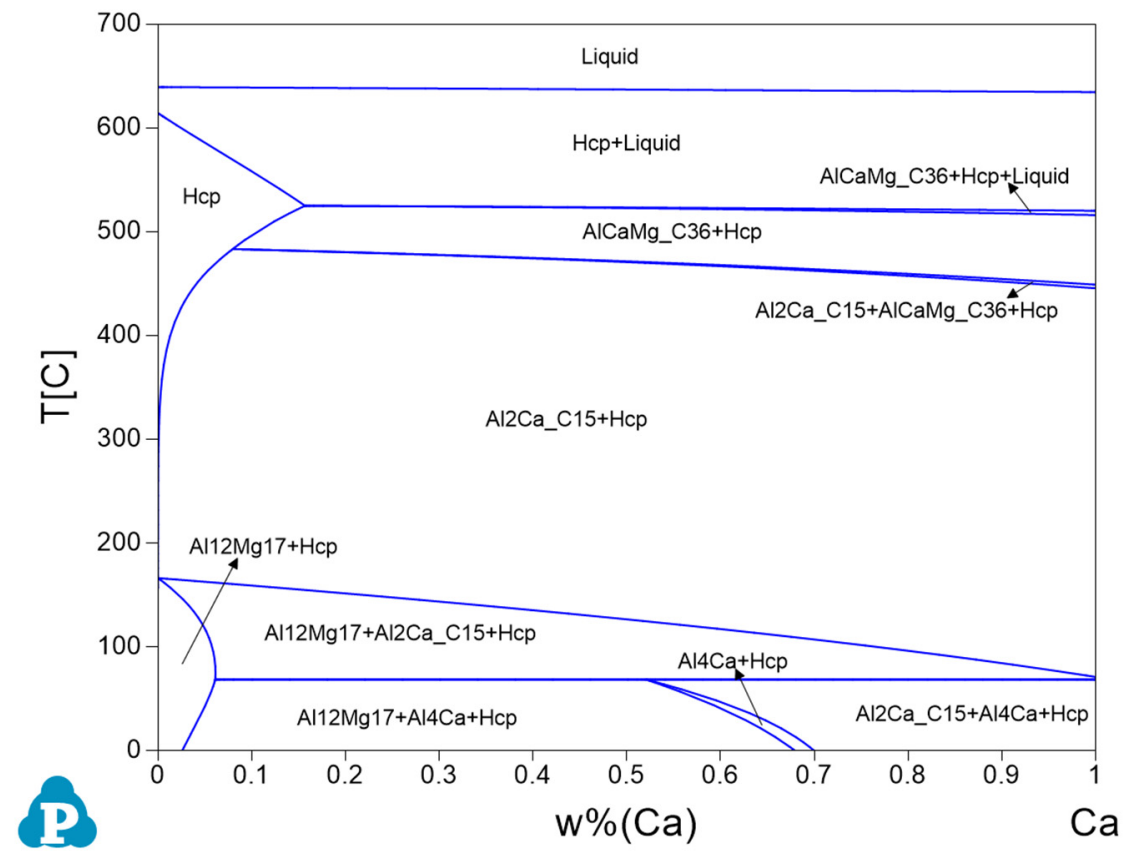

Figure 3. Calculated Mg-2Al-xCa (x, $0-1$ wt.\%) phase diagram using Pandat.

(a)

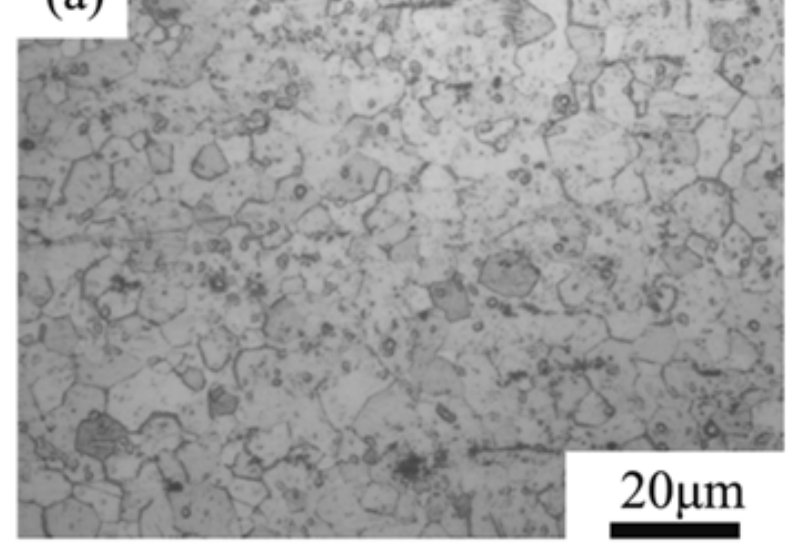

(c)

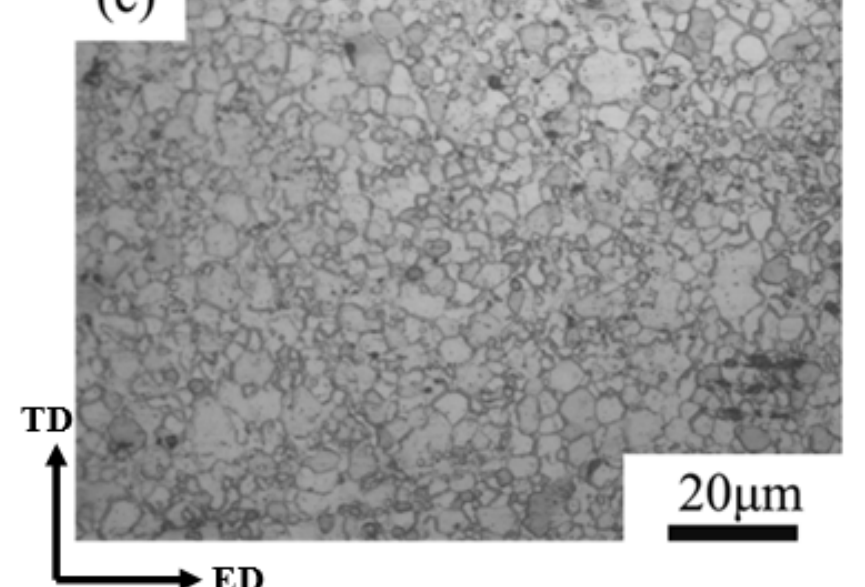

(b)

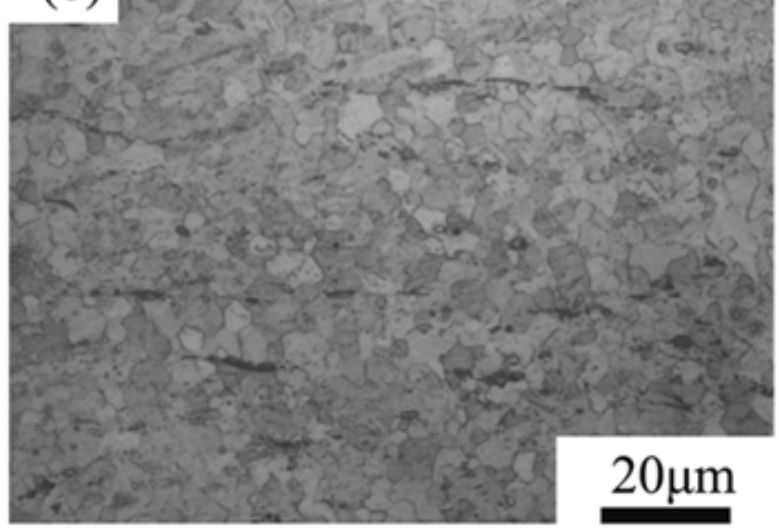

(d)

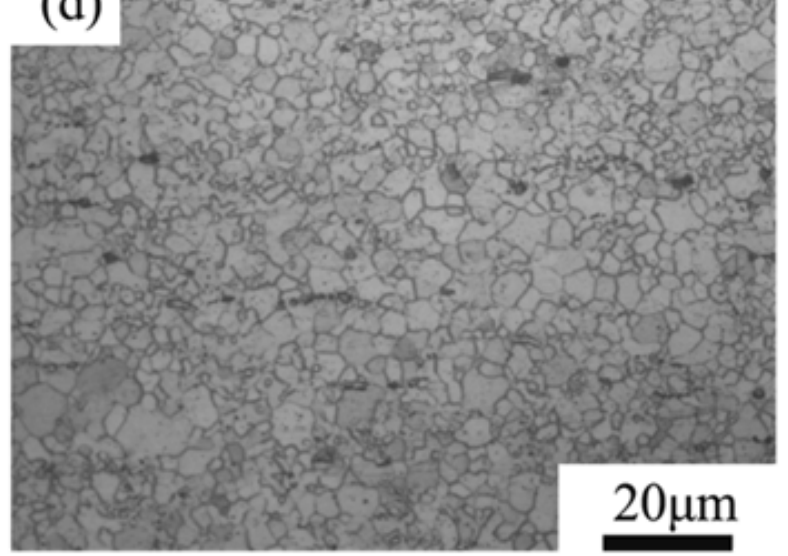

Figure 4. Optical micrographs of the as-extruded sheets: (a) alloy 1, (b) alloy 2, (c) alloy 3, and (d) alloy 4. ED (extrude direction)-TD (transverse direction) plane. 
(a)

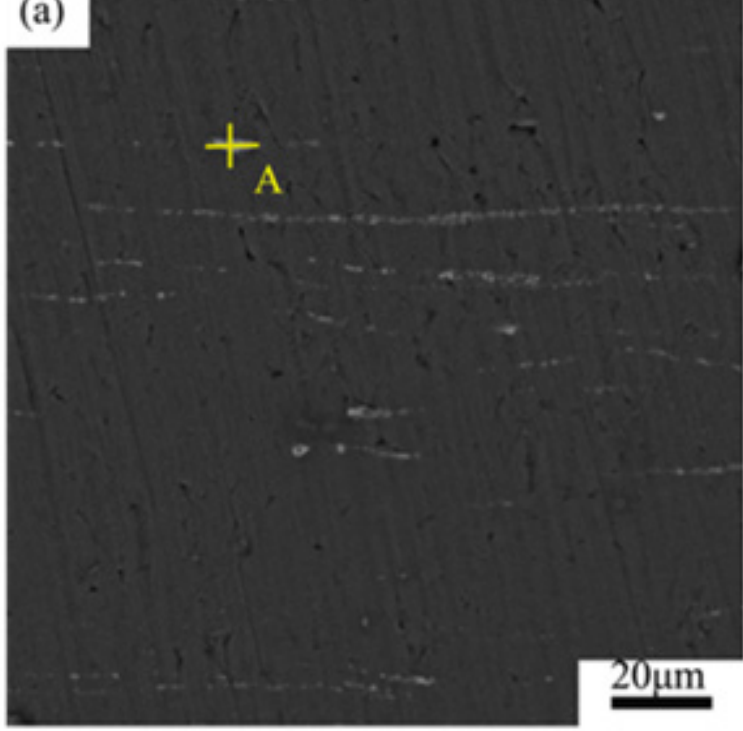

(c)

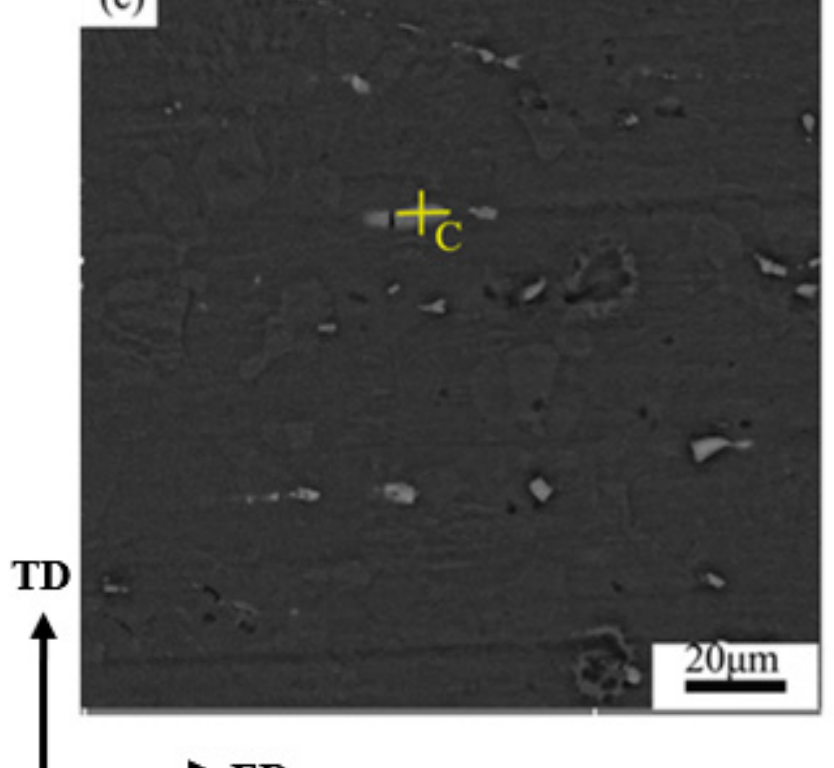

(b)

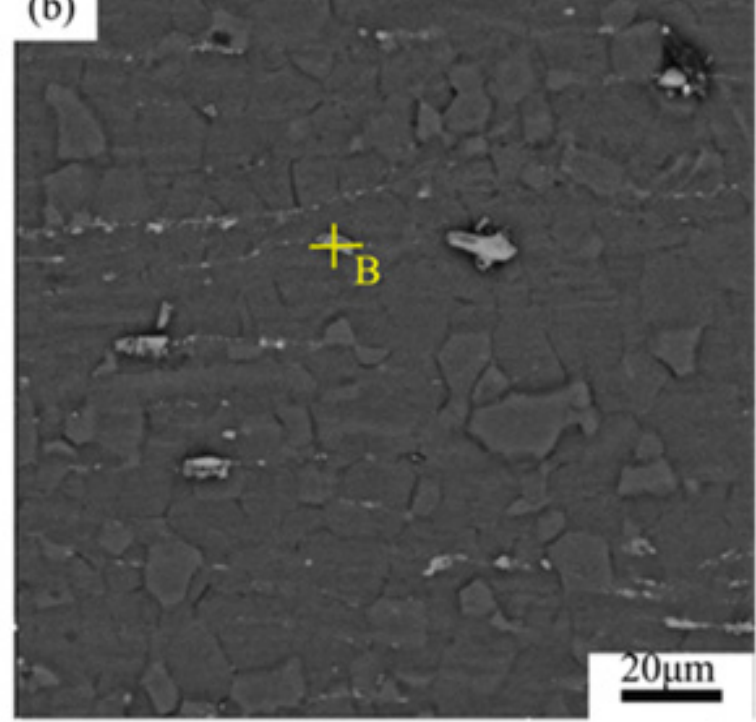

(d)

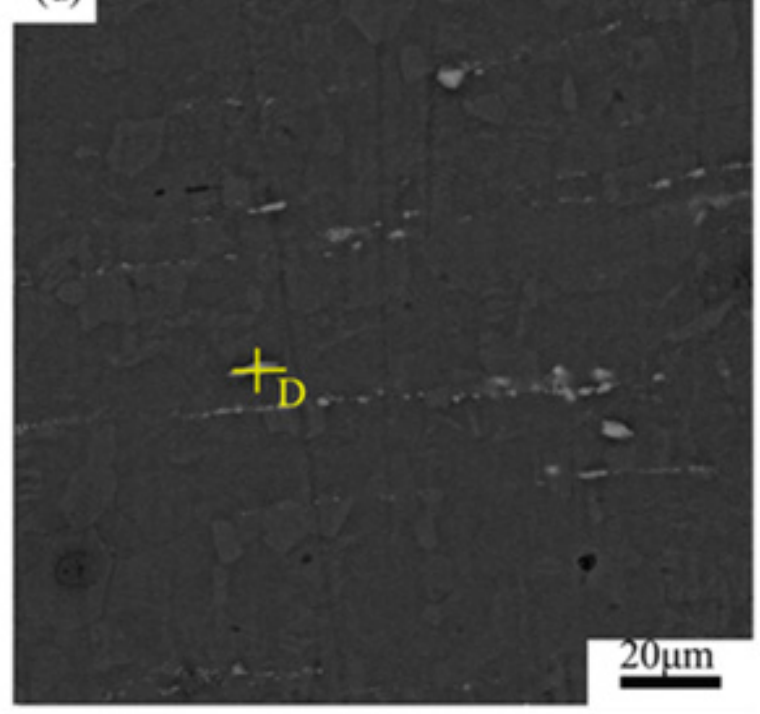

ED

Figure 5. SEM micrographs of the extruded sheets: (a) alloy 1, (b) alloy 2, (c) alloy 3, and (d) alloy 4. A-D are point EDS of the second phases.

Table 3. EDS analysis of the second phases on the extruded sheets marked in Figure 4.

\begin{tabular}{ccccc}
\hline Position & Mg & Ca & Al & Possible Phases \\
\hline A & 75.5 & 8.29 & 16.21 & $\mathrm{Al}_{2} \mathrm{Ca}$ \\
B & 41.7 & 16.58 & 41.72 & $\mathrm{Al}_{2} \mathrm{Ca}$ \\
C & 61.33 & 9.7 & 28.96 & $\mathrm{Al}_{2} \mathrm{Ca}$ \\
D & 50.74 & 12.86 & 36.4 & $\mathrm{Al}_{2} \mathrm{Ca}$ \\
\hline
\end{tabular}




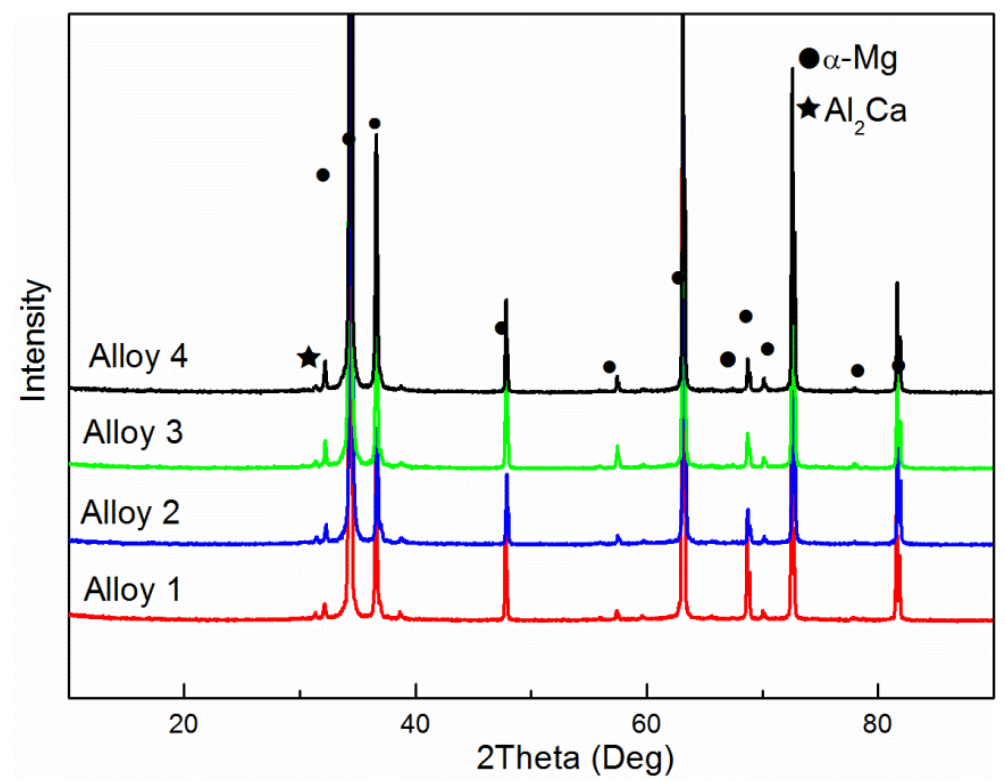

Figure 6. X-ray diffraction spectra of the extruded sheets.

To more accurately illustrate the microstructure of the as-extruded sample, EBSD inverse pole figure (IPF) maps, (0002) basal pole figures, and grain size distribution maps of the as-extruded $\mathrm{Mg}-2 \mathrm{Al}-0.5 \mathrm{Ca}-\mathrm{xZn}$ samples are shown in Figure 7 . It can be seen that all the samples display fully recrystallized microstructures, and the average grain size of alloy 1, alloy 2, alloy 3, and alloy 4 is $8.8 \mu \mathrm{m}, 6.1 \mu \mathrm{m}, 4.3 \mu \mathrm{m}$, and $5.7 \mu \mathrm{m}$, respectively. According to the (0002) basal pole figure, it can be seen that the (0002) basal poles are tilted $\sim \pm 20^{\circ}$ from the ND toward the ED. In addition, when the Zn addition increases, the (0002) basal poles spread toward the TD slightly. In addition, the maximum texture intensity of alloy 1 is $\sim 13.7 \mathrm{mrd}$, and texture intensities decrease to 8.4 8.9 after Zn addition. It is widely reported that the segregation of solute atoms along the grain boundary (GB) could suppress the recrystallization rate, and result in a weak texture [33,34]. Figure 8 shows the HAADF-STEM image and corresponding EDX maps of the as-extruded Mg2Al-0.5Ca-0.6Zn alloy. It shows the obvious segregation of $\mathrm{Zn}$ atoms along GBs, but the Ca segregation is not observed. It is hypothesized that $\mathrm{Al}_{2} \mathrm{Ca}$ particles, which are formed during the solidification, consume the majority of $\mathrm{Ca}$ elements, and the $\mathrm{Al}_{2} \mathrm{Ca}$ particles are very stable because it has a high melting point $\left(1079{ }^{\circ} \mathrm{C}\right)$. These $\mathrm{Al}_{2} \mathrm{Ca}$ particles will not decompose or transform to other phases during the homogenization and extrusion process; thus, there are few $\mathrm{Ca}$ elements in the $\mathrm{Mg}$ matrix. The segregation of $\mathrm{Zn}$ atoms along GBs reduces the grain boundary mobility and enhances the solute dragging effect [35], thus suppressing the growth of dynamic recrystallized (DRX) grains and weakening the recrystallization texture [35-37]. It is widely reported that texture weakening is conducive to a high ductility of $\mathrm{Mg}$ alloy [38-41]. In this study, $0.6 \mathrm{wt} . \% \mathrm{Zn}$ addition in the Mg-2Al$0.5 \mathrm{Ca}$ alloy not only weakens the texture but also refines the grain size, which are both beneficial to the improvement of the ductility of the Mg-2Al-0.5Ca alloy. Therefore, we can conclude that $\mathrm{Zn}$ addition could refine the grain size and weaken the texture intensity of the as-extruded $\mathrm{Mg}-2 \mathrm{Al}-0.5 \mathrm{Ca}$ alloy. 

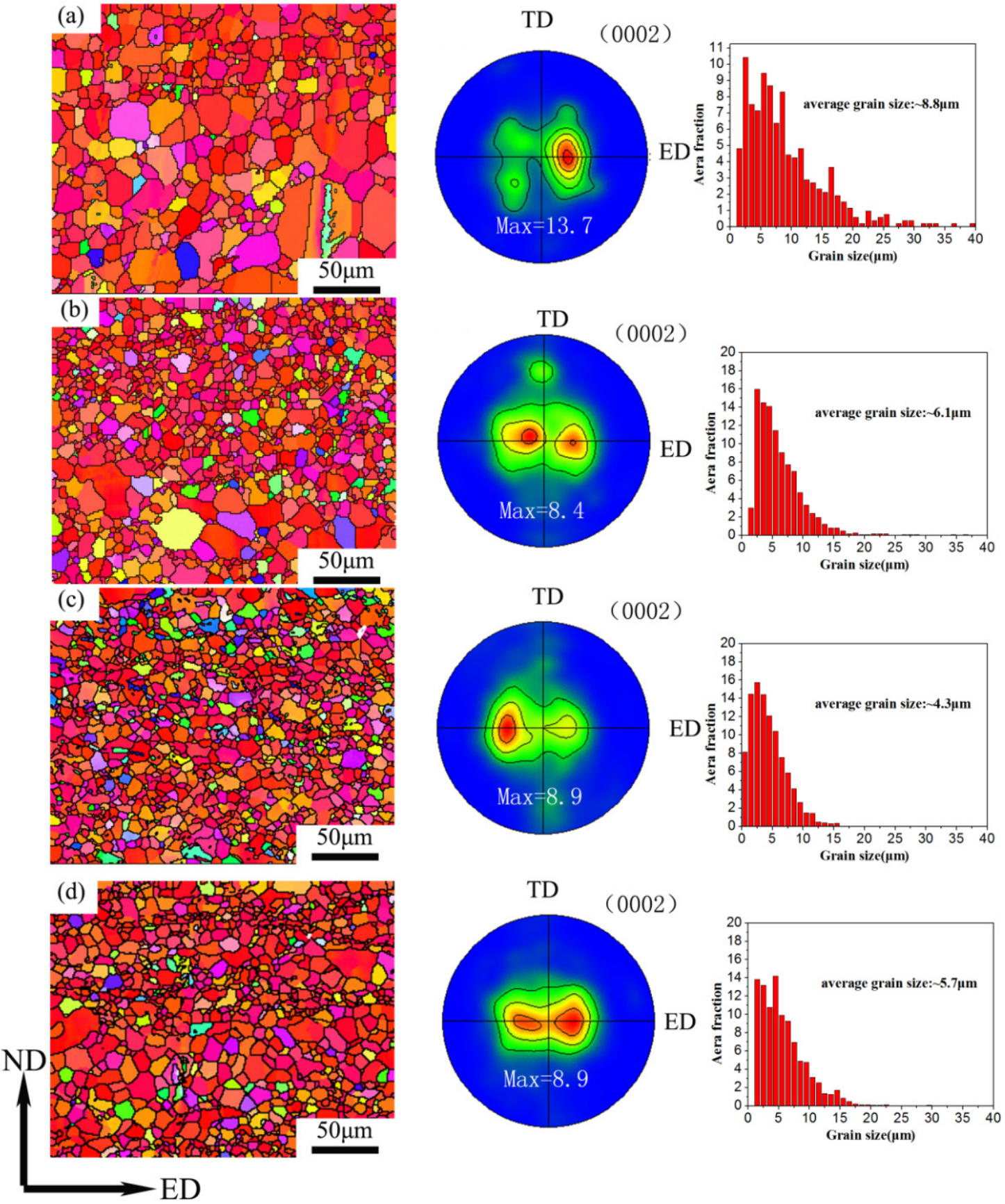

Figure 7. Inverse pole figure, pole figure, and grain size distribution maps of the sheets: (a) alloy 1 , (b) alloy 2, (c) alloy 3, and (d) alloy 4. 


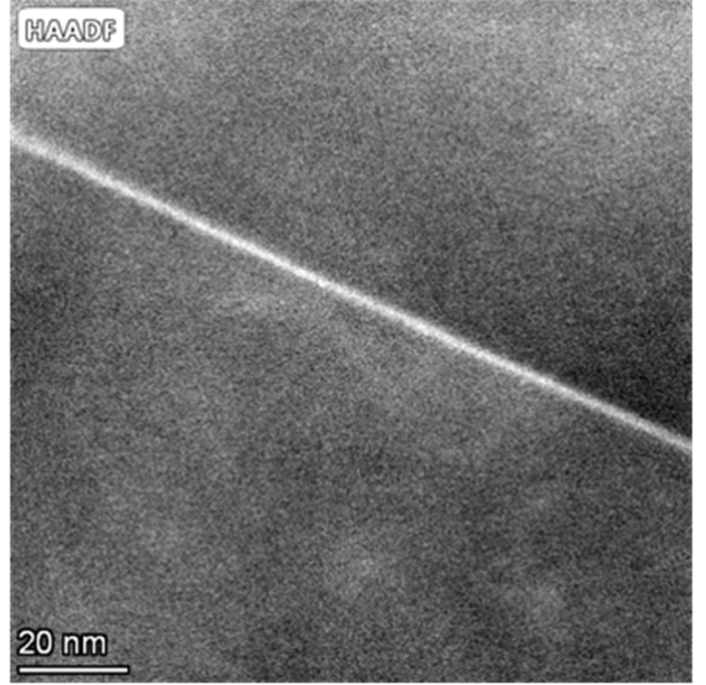

(a)

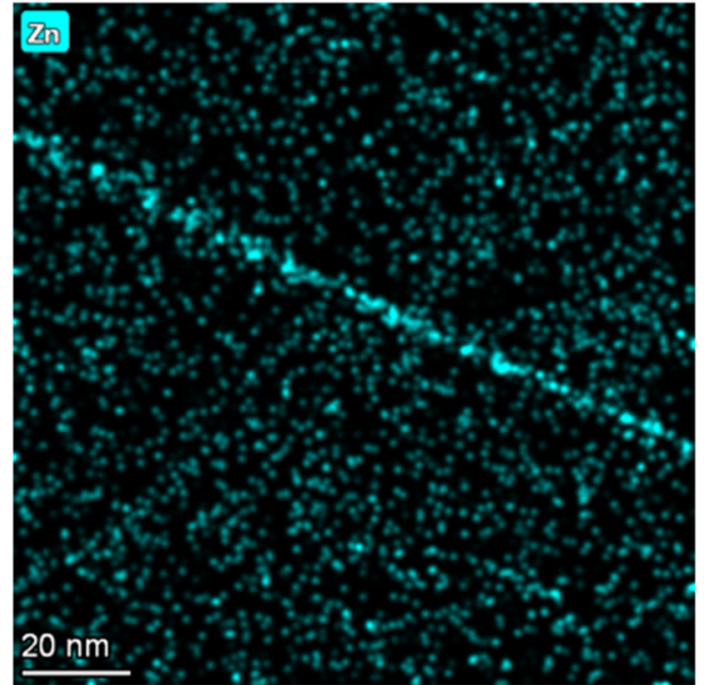

(c)

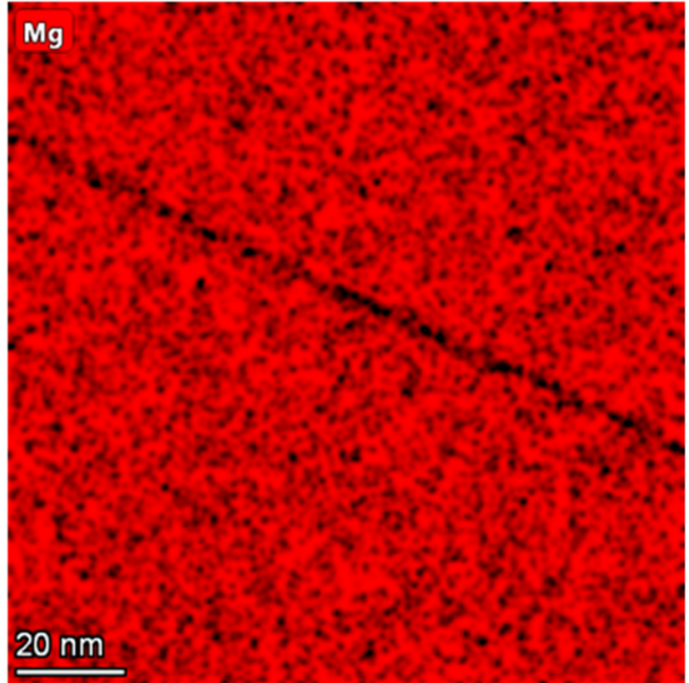

(b)

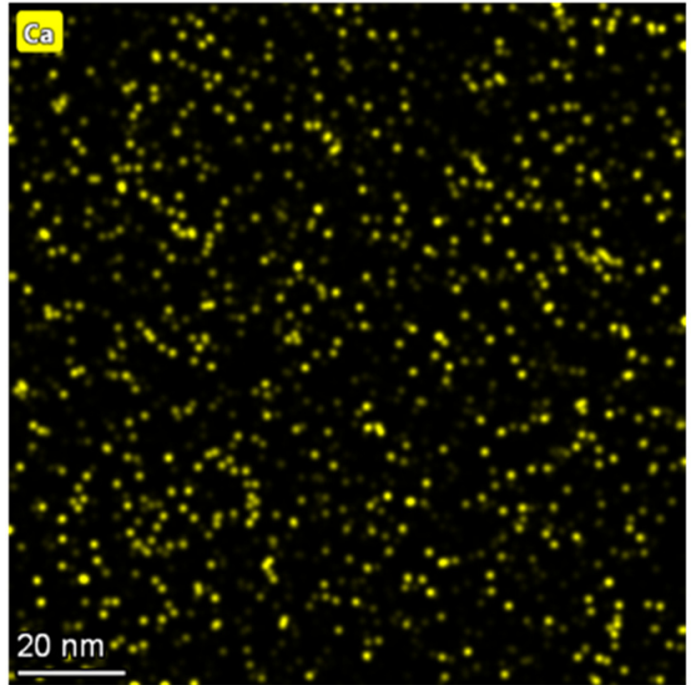

(d)

Figure 8. HAADF-STEM image and corresponding EDX maps of the as-extruded Mg-2Al-0.5Ca0.6Zn alloy: (a) HAADF-STEM image, (b-d) EDX maps of (b) Mg element, (c) Zn element and (d) Ca elements.

\subsection{Mechanical Properties}

Figure 9 shows typical true stress-strain curves of the as-extruded sheets stretched along the ED, $45^{\circ}$ direction, and TD, respectively. The values of $0.2 \%$ yield strength (YS), ultimate tensile strength (UTS), and elongation to failure $(\varepsilon)$ are presented in Table 4 . As shown in Figure 7a, alloy 1 exhibits a YS and UTS of 110 and $236 \mathrm{MPa}$ along the ED, respectively, and the YS and UTS are 139 and $271 \mathrm{MPa}$ for the $45^{\circ}$ direction and 119 and $248 \mathrm{MPa}$ for the TD, respectively. The $\varepsilon$ along the $\mathrm{ED}, 45^{\circ}$ direction, and TD are $20.1 \%$, $21.7 \%$, and $16.1 \%$, respectively. With the addition of $0.3 \mathrm{wt} . \% \mathrm{Zn}$, alloy 2 shows obvious improvements in YS and UTS along the ED, which are 142 and $297 \mathrm{MPa}$, respectively, and the $\varepsilon$ is $23.3 \%$; these are larger than those of alloy 1 . As shown in Figure $7 c$, alloy 3 shows a similar YS for all three loading directions; the YS, UTS, and $\varepsilon$ of alloy 3 are simultaneously enhanced to $145 \mathrm{MPa}, 317 \mathrm{MPa}$, and $30.0 \%$ along the ED; $148 \mathrm{MPa}, 299 \mathrm{MPa}$, and $25.0 \%$ along the $45^{\circ}$ direction; and $148 \mathrm{MPa}, 269 \mathrm{MPa}$, and $16.8 \%$ along the TD, respectively. As shown in Figure $7 d$, when the Zn addition is $0.9 \mathrm{wt} . \%$, alloy 4 shows a YS, UTS, and $\varepsilon$ of $149 \mathrm{MPa}, 327 \mathrm{MPa}$, and $28.6 \%$ along the ED and $152 \mathrm{MPa}, 258 \mathrm{MPa}$, and $13.6 \%$ along the $\mathrm{TD}$, respectively. By comparing YS vs. $\varepsilon$ for alloy 3 and alloy 4 , although alloy 4 shows 
a little higher strength compared to alloy 3 , the ductility of alloy 4 is lower than that of alloy 3. As observed, dilute addition of $\mathrm{Zn}$ could improve the strength and ductility of the as-extruded sheet, indicating that $\mathrm{Zn}$ micro-alloying is an effective method to improve the mechanical properties of $\mathrm{Mg}$-Al-Ca-based alloys. When the $\mathrm{Zn}$ addition is $0.6 \mathrm{wt} . \%$, the alloy shows a good balance between strength and ductility.

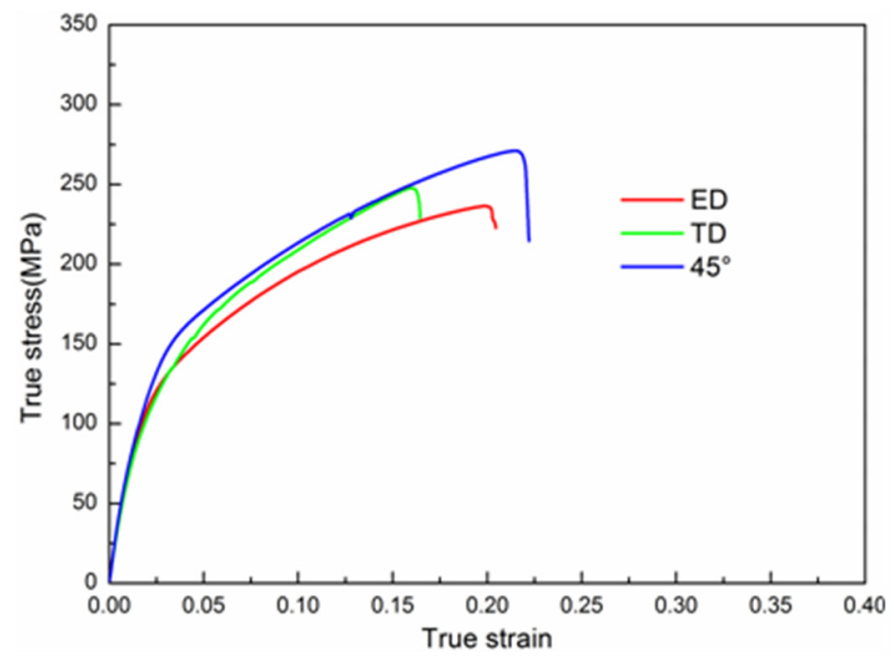

(a)

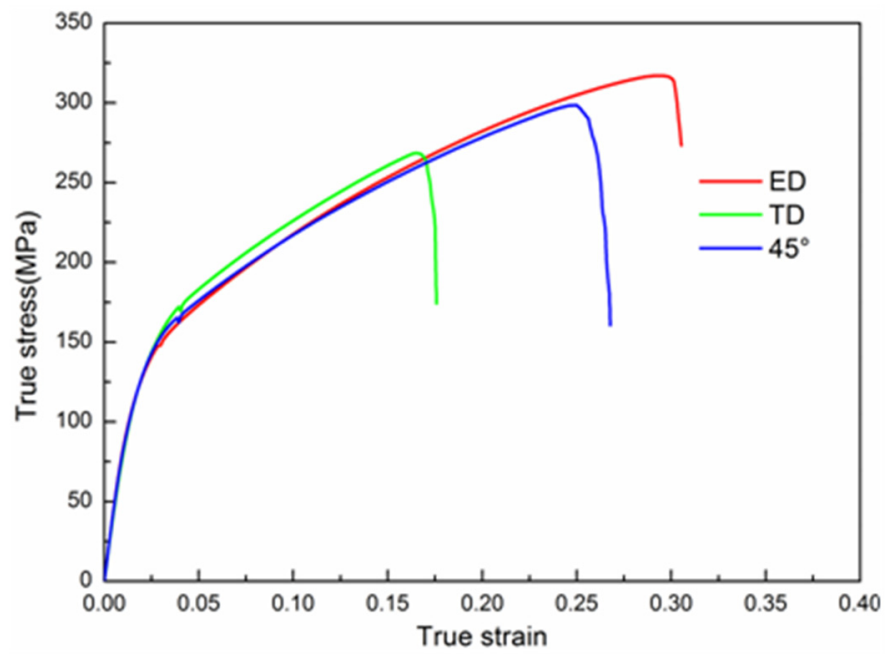

(c)

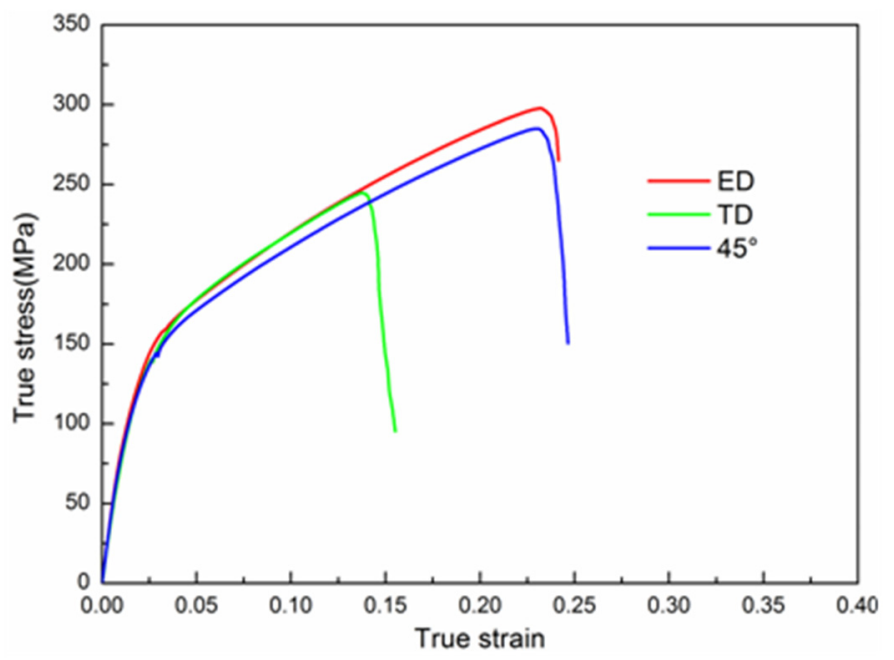

(b)

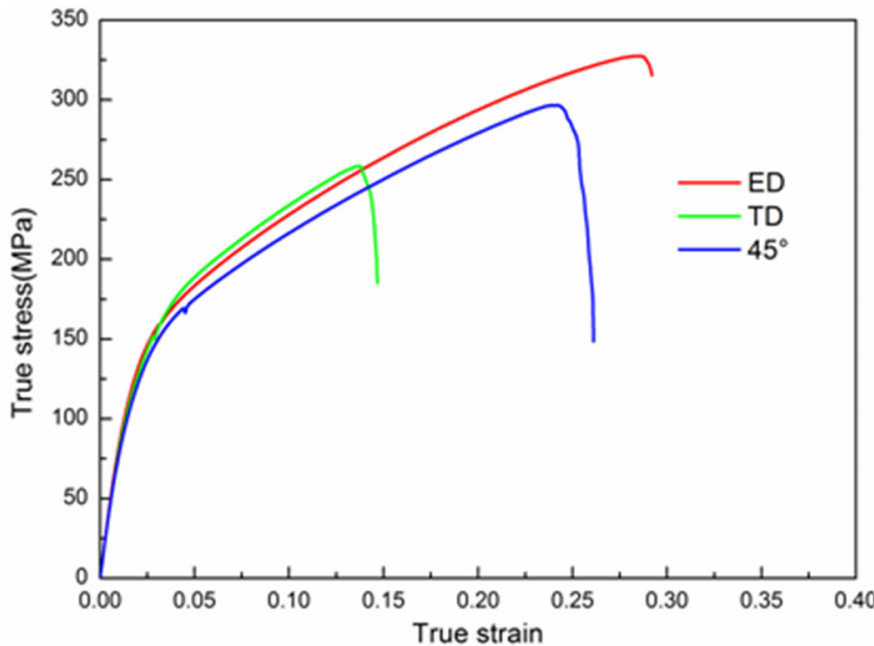

(d)

Figure 9. Typical true stress-strain curves of as-extruded sheets: (a) alloy 1, (b) alloy 2, (c) alloy 3, and (d) alloy 4.

Table 4. Tensile properties of the alloys at room temperature (RM).

\begin{tabular}{|c|c|c|c|c|c|c|c|c|c|}
\hline \multirow{2}{*}{ Alloy } & \multicolumn{3}{|c|}{ ED } & \multicolumn{3}{|c|}{$45^{\circ}$} & \multicolumn{3}{|c|}{ TD } \\
\hline & $\sigma_{0.2}$ & $\sigma_{\mathbf{b}}$ & $\varepsilon$ & $\sigma_{0.2}$ & $\sigma_{b}$ & $\varepsilon$ & $\sigma_{0.2}$ & $\sigma_{\mathbf{b}}$ & $\varepsilon$ \\
\hline Alloy 1 & $110 \pm 3$ & $236 \pm 5$ & $20.1 \pm 0.8$ & $139 \pm 2$ & $271 \pm 3$ & $21.7 \pm 0.6$ & $119 \pm 2$ & $248 \pm 2$ & $16.1 \pm 0.4$ \\
\hline Alloy 2 & $142 \pm 2$ & $297 \pm 4$ & $23.3 \pm 0.6$ & $140 \pm 2$ & $285 \pm 4$ & $23.1 \pm 0.5$ & $142 \pm 3$ & $245 \pm 2$ & $13.9 \pm 0.8$ \\
\hline Alloy 3 & $145 \pm 2$ & $317 \pm 4$ & $30.0 \pm 0.4$ & $148 \pm 2$ & $299 \pm 3$ & $25.0 \pm 0.3$ & $148 \pm 2$ & $269 \pm 4$ & $16.8 \pm 0.6$ \\
\hline Alloy 4 & $149 \pm 2$ & $327 \pm 3$ & $28.6 \pm 0.5$ & $142 \pm 2$ & $297 \pm 2$ & $24.1 \pm 0.4$ & $152 \pm 2$ & $258 \pm 3$ & $13.6 \pm 0.5$ \\
\hline
\end{tabular}

Figure 10 shows the tensile fracture surfaces of as-extruded sheet samples stretched along the ED. It can be seen that there are many shear cleavage planes and tear ridges on the fracture surface of alloy 1 , which shows a quasi-cleavage transgranular fracture. With the 
addition of $0.3 \mathrm{wt} . \% \mathrm{Zn}$, some dimples appear on the fracture surface of alloy 2 . With the $\mathrm{Zn}$ content reaching $0.6 \mathrm{wt} . \%$, the fracture surfaces of alloy 3 contain numerous fine-scale deep dimples, which means that alloy 3 shows a ductile fracture. With the further increase in $\mathrm{Zn}$ content, the dimples on the fracture surface of alloy 4 decrease, which means the elongation of alloy 4 decreases again. As a result, it can be concluded that the trace $\mathrm{Zn}$ addition causes significant changes in the tensile fracture surface of the as-extruded Mg-Al-Ca alloys, and these changes are consistent with the performance of the alloys' ductility.
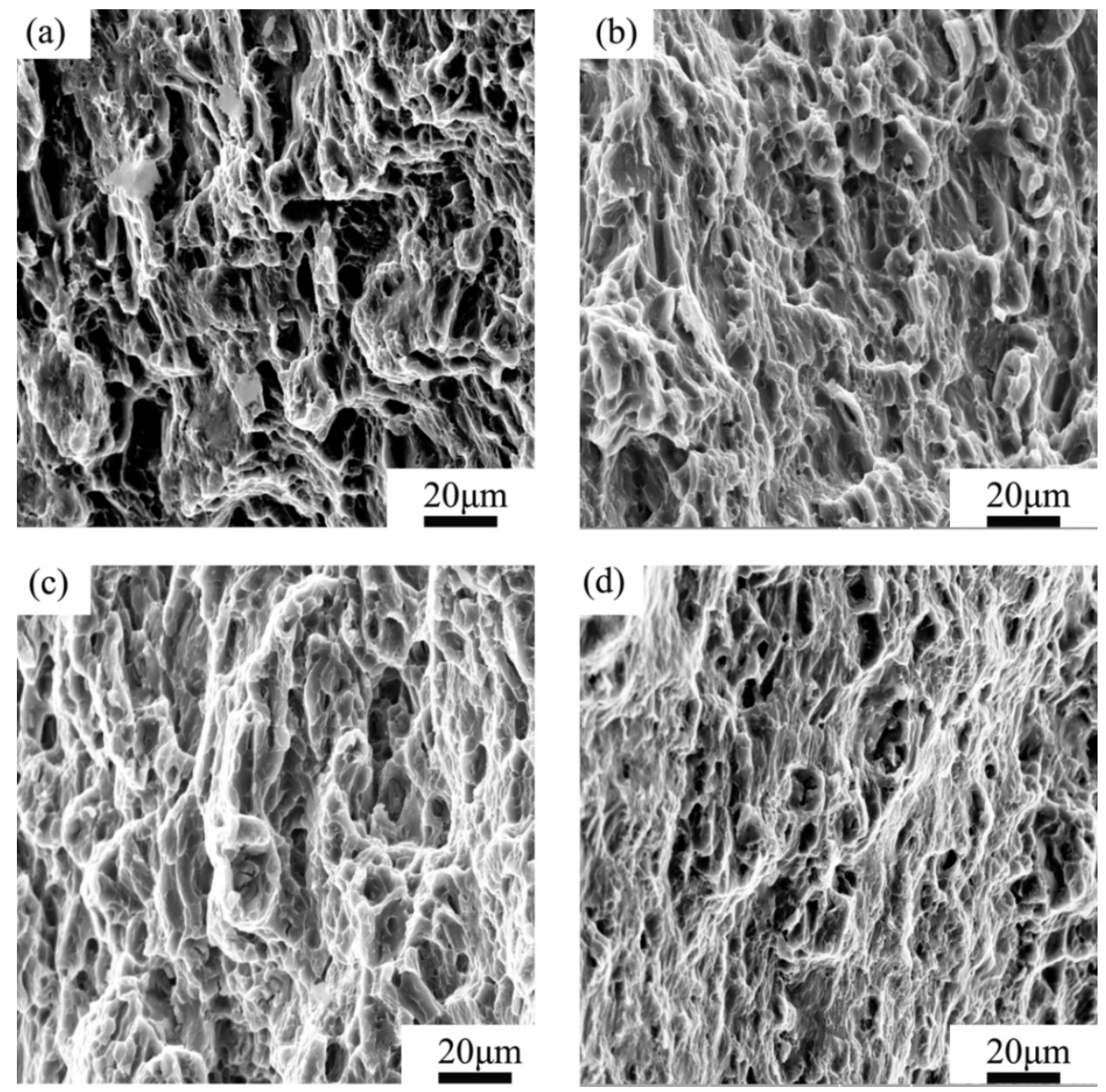

Figure 10. Tensile fracture surfaces of as-extruded alloy sheets stretched along the ED: (a) alloy 1, (b) alloy 2, (c) alloy 3, and (d) alloy 4.

\section{Discussion}

It is widely reported that grain size reduction, solid solution strengthening, precipitation strengthening, and second-phase strengthening could increase the strength of the Mg-based alloys [31,42]. In this work, Mg-2Al-0.5Ca alloys with $\mathrm{Zn}$ addition showed better mechanical properties compared to the Zn-free alloy. According to the microstructural analysis above, grain boundary strengthening and solid-solution strengthening were two of the dominant factors responsible for the enhanced YS of the Mg alloys.

Figure 11 shows the effect of grain size on the yield stress of the extruded alloys. It can be seen that the smaller the grain size, the higher the strength of the alloy. According to the Hall-Petch equation $\Delta \sigma_{g s}=k d^{-1 / 2}$ [43], where $k$ is the Hall-Petch constant and $d$ is the average grain size, we can calculate the Hall-Petch slope as $254 \mathrm{MPa} / \mu \mathrm{m}^{0.5}$. This value is consistent with the reported values for $\mathrm{Mg}$ alloys [43]. Thus, the grain boundary strengthening $\left(\Delta \sigma_{g s}\right)$ can be calculated to be $85.6 \mathrm{MPa}, 102.9 \mathrm{MPa}, 122.5 \mathrm{MPa}$, and 106.4 $\mathrm{MPa}$ for 
extruded alloy 1, alloy 2, alloy 3, and alloy 4, respectively. Therefore, when the Zn content is $0.6 \mathrm{wt}$.\%, the grain size of alloy 3 is smallest, and the grain boundary strengthening is increased by $37 \mathrm{MPa}$.

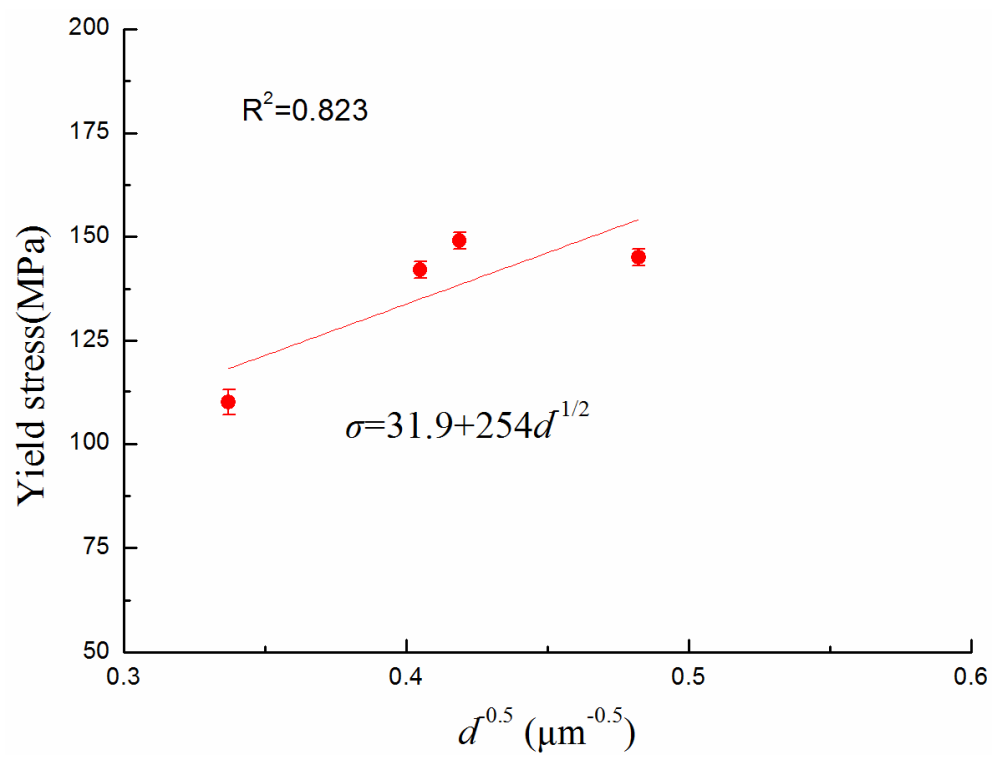

Figure 11. The corresponding Hall-Petch plot.

The solid solution strengthening effect of solutes arises from the size misfit and modulus misfit parameters. The $\mathrm{Zn}$ atom is recognized to be one of the effective solute atoms for increasing the strength when it is added into $\mathrm{Mg}$ alloys [44], because of the difference in the atomic radius between $\mathrm{Zn}$ and $\mathrm{Mg}$, and the wide range of solubility. Regardless of whether the $\mathrm{Mg}$ alloy undergoes plastic deformation or not, its intrinsic crystal structure does not change. Namely, the lattice distortion and modulus effect caused by solution atoms is expected to not change noticeably. The solid solution strengthening can be calculated using the following equation [45]:

$$
\Delta \sigma_{s S}=\left(k_{i}^{1 / n} C_{i}\right)^{n}
$$

where $C_{i}$ is the concentrations of the solute atoms, $n$ is taken as $2 / 3$, and $k_{i}$ is a factor related to individual solute elements, which is taken as $40 \mathrm{MPa}$ (at.\%) ${ }^{-2 / 3}$ for $\mathrm{Zn}$ [46]. Then, we can calculate the strength provided by the $\mathrm{Zn}$ solid solution, as $9.2 \mathrm{MPa}, 14.4 \mathrm{MPa}$, and $18 \mathrm{MPa}$ for extruded alloy 2, alloy 3, and alloy 4, respectively. Thus, the solution strengthening due to $\mathrm{Zn}$ addition is not as obvious as the fine grain strengthening. In this work, the improvement in both strength and ductility of the Mg-2Al-0.5Ca alloy sheet is achieved through $0.6 \mathrm{wt}$ \% of $\mathrm{Zn}$ addition. Compared to the AZ series alloy [47,48], the $\mathrm{Mg}-2 \mathrm{Al}-0.5 \mathrm{Ca}-0.6 \mathrm{Zn}$ alloy shows improved mechanical properties, with a relatively low content of alloying additions. This study is expected to contribute to the development of promising strong, ductile, and low-cost $\mathrm{Mg}$ alloy sheets.

\section{Conclusions}

In this study, the microstructure, texture, and mechanical properties of as-extruded Mg-2Al-0.5Ca-xZn alloys with different $\mathrm{Zn}$ additions were investigated. It was found that grain size was refined and texture weakening was achieved with the $\mathrm{Zn}$ addition in the Mg-2Al-0.5C alloys. The addition of $0.6 \mathrm{wt} \% \mathrm{Zn}$ improved the tensile strength and ductility of the as-extruded $\mathrm{Mg}-2 \mathrm{Al}-0.5 \mathrm{Ca}$ alloy sheet, which showed a $0.2 \%$ proof stress of $145 \mathrm{MPa}$, an ultimate tensile strength of $316 \mathrm{MPa}$, and an elongation of $30.0 \%$ along the extruded direction. The combination improvement of strength and ductility was mainly due to the fine and homogeneous grain microstructure and the weakened ED- 
tilted texture. The as-extruded sheet showed little in-plane anisotropic tensile properties. The $0.2 \%$ proof stress, ultimate tensile strength, and elongation in the $45^{\circ}$ direction were $148 \mathrm{MPa}, 299 \mathrm{MPa}$, and $25.0 \%$, and those in the transverse direction were $148 \mathrm{MPa}, 269 \mathrm{MPa}$, and $16.8 \%$, respectively.

Author Contributions: Conceptualization, M.Y. and B.J.; methodology, M.Y.; software, X.Q.; validation, Z.D., J.Z. and H.Y.; formal analysis, C.H.; investigation, Y.S., Y.C. and B.L.; writing-original draft preparation, M.Y.; writing—review and editing, M.Y. and B.J.; funding acquisition, M.Y., Z.D., B.J. and F.P. All authors have read and agreed to the published version of the manuscript.

Funding: The authors are grateful for the financial support from the National Natural Science Foundation of China (Project No.52001037, No.U2037601, No.51971044, No.51531002, No.52101126, No.U21A2048, and U1764253), the Middle-aged and Young of the Education Department of Hubei Province (Project No.Q20162703), the Qinghai Science and Technology Program (2018-GX-A1), and the Natural Science Foundation of Chongqing (Project No. cstc2019jcyj-msxmX0234).

Institutional Review Board Statement: Not applicable.

Informed Consent Statement: Not applicable.

Data Availability Statement: Not applicable.

Conflicts of Interest: The authors declare no conflict of interest.

\section{References}

1. Sasaki, T.T.; Bian, M.Z.; Li, Z.H.; Hono, K. Toward Development of Strong and Formable Magnesium Alloy Sheets with Bake-Hardenability. JOM 2021, 73, 1471-1483. [CrossRef]

2. Zhao, L.-Q.; Wang, C.; Chen, J.-C.; Ning, H.; Yang, Z.-Z.; Xu, J.; Wang, H.-Y. Development of weak-textured and high-performance $\mathrm{Mg}-\mathrm{Zn}-\mathrm{Ca}$ alloy sheets based on Zn content optimization. J Alloy. Compd. 2020, 849, 156640. [CrossRef]

3. Papenberg, N.P.; Gneiger, S.; Uggowitzer, P.J.; Pogatscher, S. Lean Wrought Magnesium Alloys. Materials 2021, 14, 4282. [CrossRef] [PubMed]

4. Song, J.; She, J.; Chen, D.; Pan, F. Latest research advances on magnesium and magnesium alloys worldwide. J. Magnes. 2020, 8 , 1-41. [CrossRef]

5. You, S.; Huang, Y.; Kainer, K.U.; Hort, N. Recent research and developments on wrought magnesium alloys. J. Magnes. Alloy. 2017, 5, 239-253. [CrossRef]

6. Salandari-Rabori, A.; Zarei-Hanzaki, A.; Abedi, H.R.; Lecomte, J.S.; Khatami-Hamedani, H. Micro and macro texture evolution during multiaxial forging of a WE43 magnesium alloy. J Alloy. Compd. 2018, 739, 249-259. [CrossRef]

7. Jiang, M.G.; Xu, C.; Nakata, T.; Yan, H.; Chen, R.S.; Kamado, S. Rare earth texture and improved ductility in a Mg-Zn-Gd alloy after high-speed extrusion. Mater. Sci. Eng. A 2016, 667, 233-239. [CrossRef]

8. Bugnet, M.; Kula, A.; Niewczas, M.; Botton, G.A. Segregation and clustering of solutes at grain boundaries in Mg-rare earth solid solutions. Acta Mater. 2014, 79, 66-73. [CrossRef]

9. Basu, I.; Al-Samman, T. Triggering rare earth texture modification in magnesium alloys by addition of zinc and zirconium. Acta Mater. 2014, 67, 116-133. [CrossRef]

10. Stanford, N. Micro-alloying Mg with $\mathrm{Y}, \mathrm{Ce}, \mathrm{Gd}$ and La for texture modification-A comparative study. Mater. Sci. Eng. A 2010, 527, 2669-2677. [CrossRef]

11. Illkova, K.; Dobroň, P.; Chmelík, F.; Kainer, K.U.; Balík, J.; Yi, S.; Letzig, D.; Bohlen, J. Effect of aluminium and calcium on the microstructure, texture, plastic deformation and related acoustic emission of extruded magnesium-manganese alloys. J. Alloy. Compd. 2014, 617, 253-264. [CrossRef]

12. Stanford, N. The effect of calcium on the texture, microstructure and mechanical properties of extruded Mg-Mn-Ca alloys. Mater Sci. Eng. A 2010, 528, 314-322. [CrossRef]

13. Bohlen, J.; Wendt, J.; Nienaber, M.; Kainer, K.U.; Stutz, L.; Letzig, D. Calcium and zirconium as texture modifiers during rolling and annealing of magnesium-zinc alloys. Mater. Charact. 2015, 101, 144-152. [CrossRef]

14. Nakata, T.; Xu, C.; Ajima, R.; Shimizu, K.; Hanaki, S.; Sasaki, T.T.; Ma, L.; Hono, K.; Kamado, S. Strong and ductile age-hardening Mg-Al-Ca-Mn alloy that can be extruded as fast as aluminum alloys. Acta Mater. 2017, 130, 261-270. [CrossRef]

15. Watanabe, H.; Yamaguchi, M.; Takigawa, Y.; Higashi, K. Mechanical properties of Mg-Al-Ca alloy processed by hot extrusion. Mater. Sci. Eng. A 2007, 454, 384-388. [CrossRef]

16. Xu, S.W.; Oh-ishi, K.; Kamado, S.; Uchida, F.; Homma, T.; Hono, K. High-strength extruded Mg-Al-Ca-Mn alloy. Scr. Mater. 2011, 65, 269-272. [CrossRef]

17. Kim, J.H.; Kang, N.E.; Chang, D.Y.; Kim, B.K. Effect of calcium content on the microstructural evolution and mechanical properties of wrought Mg-3Al-1Zn alloy. Mater. Sci. Eng. A 2009, 525, 18-29. [CrossRef] 
18. Huang, X.; Chino, Y.; Yuasa, M.; Ueda, H.; Inoue, M.; Kido, F.; Matsumoto, T. Microstructure and mechanical properties of AZX912 magnesium alloy extruded at different temperatures. Mater. Sci. Eng. A 2017, 679, 162-171. [CrossRef]

19. SandloBes, S.; Friák, M.; Korte-Kerzel, S.; Pei, Z.; Neugebauer, J.; Raabe, D. A rare-earth free magnesium alloy with improved intrinsic ductility. Sci. Rep. 2017, 7, 10458. [CrossRef]

20. Masood Chaudry, U.; Hoo Kim, T.; Duck Park, S.; Sik Kim, Y.; Hamad, K.; Kim, J.-G. On the High Formability of AZ31-0.5Ca Magnesium Alloy. Materials 2018, 11, 2201. [CrossRef]

21. Ding, H.; Zhang, P.; Cheng, G.; Kamado, S. Effect of calcium addition on microstructure and texture modification of Mg rolled sheets. Trans. Nonferrous Met. Soc. China 2015, 25, 2875-2883. [CrossRef]

22. Li, Z.H.; Sasaki, T.T.; Bian, M.Z.; Nakata, T.; Yoshida, Y.; Kawabe, N.; Kamado, S.; Hono, K. Effects of Zn Additions on the Room Temperature Formability and Strength in $\mathrm{Mg}-1.2 \mathrm{Al}-0.5 \mathrm{Ca}-0.4 \mathrm{Mn}$ Alloy Sheets; Springer International Publishing: Cham, Germany, 2020; pp. 105-111.

23. Golrang, M.; Mobasheri, M.; Mirzadeh, H.; Emamy, M. Effect of Zn addition on the microstructure and mechanical properties of Mg-0.5Ca-0.5RE magnesium alloy. J Alloy. Compd. 2020, 815, 152380. [CrossRef]

24. Chai, Y.; Jiang, B.; Song, J.; Liu, B.; Huang, G.; Zhang, D.; Pan, F. Effects of Zn and Ca addition on microstructure and mechanical properties of as-extruded Mg-1.0Sn alloy sheet. Mater. Sci. Eng. A 2019, 746, 82-93. [CrossRef]

25. Wang, F.; Hu, T.; Zhang, Y.; Xiao, W.; Ma, C. Effects of Al and Zn contents on the microstructure and mechanical properties of Mg-Al-Zn-Ca magnesium alloys. Mater. Sci. Eng. A 2017, 704, 57-65. [CrossRef]

26. Zhao, C.; Chen, X.; Pan, F.; Wang, J.; Gao, S.; Tu, T.; Liu, C.; Yao, J.; Atrens, A. Strain hardening of as-extruded Mg-xZn (x = 1, 2, 3 and 4 wt.\%) alloys. J Mater. Sci. Technol. 2019, 35, 142-150. [CrossRef]

27. Nakata, T.; Xu, C.; Suzawa, K.; Yoshida, K.; Kawabe, N.; Kamado, S. Enhancing mechanical properties of rolled Mg-Al-Ca-Mn alloy sheet by Zn addition. Mater. Sci. Eng. A 2018, 737, 223-229. [CrossRef]

28. Liu, L. 2-Welding Metallurgy of Magnesium Alloys; Woodhead Publishing: Sawston, UK, 2010; pp. 9-15.

29. Zhou, X.J.; Xiong, W.Y.; Zeng, G.; Xiao, H.C.; Zhang, J.; Lu, X.Z.; Chen, X.M. Combined effects of LPSO orientation and alpha-Mg texture on tensile anisotropy of an extruded Mg-Gd-Y-Zn-Zr alloy. Mater. Sci. Eng. A 2021, 805, 140596. [CrossRef]

30. Zhao, J.; Jiang, B.; Wang, Q.; Yang, H.; Yuan, M.; Huang, G.; Zhang, D.; Pan, F. Influence of Ce content on the microstructures and tensile properties of Mg-1Gd-0.5Zn alloys. Mater. Sci. Eng. A 2021, 823, 141675. [CrossRef]

31. Yuan, M.; He, C.; Zhao, J.; Yang, H.; Song, Y.; Lei, B.; Qian, X.; Dong, Z.; Li, Q.; Jiang, B.; et al. Microstructure evolution and mechanical properties of the Mg-Sm-Gd-Zn-Zr alloy during extrusion. J. Mater. Res. Technol. 2021, 15, 2518-2528. [CrossRef]

32. Yu, Z.J.; Xu, X.; Mansoor, A.; Du, B.T.; Shi, K.; Liu, K.; Li, S.B.; Du, W.B. Precipitate characteristics and their effects on the mechanical properties of as-extruded Mg-Gd-Li-Y-Zn alloy. J. Mater. Sci. Technol. 2021, 88, 21-35. [CrossRef]

33. Bian, M.; Huang, X.; Chino, Y. Substantial improvement in cold formability of concentrated Mg-Al-Zn-Ca alloy sheets by high temperature final rolling. Acta Mater. 2021, 220, 117328. [CrossRef]

34. Pei, R.; Zou, Y.; Wei, D.; Al-Samman, T. Grain boundary co-segregation in magnesium alloys with multiple substitutional elements. Acta Mater. 2021, 208, 116749. [CrossRef]

35. Zeng, Z.R.; Zhu, Y.M.; Xu, S.W.; Bian, M.Z.; Davies, C.H.J.; Birbilis, N.; Nie, J.F. Texture evolution during static recrystallization of cold-rolled magnesium alloys. Acta Mater. 2016, 105, 479-494. [CrossRef]

36. Guan, D.; Liu, X.; Gao, J.; Ma, L.; Wynne, B.P.; Rainforth, W.M. Exploring the mechanism of "Rare Earth" texture evolution in a lean Mg-Zn-Ca alloy. Sci. Rep. 2019, 9, 7152. [CrossRef]

37. Guan, D.; Rainforth, W.M.; Le, M.; Wynne, B.; Gao, J. Twin recrystallization mechanisms and exceptional contribution to texture evolution during annealing in a magnesium alloy. Acta Mater. 2017, 126, 132-144. [CrossRef]

38. Wang, S.; Ma, J.; Yang, J.; Zhang, W.; Sun, Y.; Pan, J.; Wang, H.; Chen, W. Improving the ductility of Mg-2.5Nd-0.5Zn-0.5Zr alloy by multi-pass hot rolling. J. Mater. Res. Technol. 2021, 14, 2124-2130. [CrossRef]

39. Wu, J.; Jin, L.; Dong, J.; Wang, F.; Dong, S. The texture and its optimization in magnesium alloy. J. Mater. Sci. Technol. 2020, 42, 175-189. [CrossRef]

40. Ding, H.; Shi, X.; Wang, Y.; Cheng, G.; Kamado, S. Texture weakening and ductility variation of Mg-2Zn alloy with CA or RE addition. Mater. Sci. Eng. A 2015, 645, 196-204. [CrossRef]

41. Ogawa, Y.; Ando, D.; Sutou, Y.; Koike, J. Texture randomization of hexagonal close packed phase through hexagonal close packed/body centered cubic phase transformation in Mg-Sc alloy. Scripta Mater. 2017, 128, 27-31. [CrossRef]

42. Zhang, D.; Yang, Q.; Guan, K.; Li, B.; Wang, N.; Qin, P.; Jiang, B.; Sun, C.; Qin, X.; Tian, Z.; et al. A high-strength low-rare-earthalloyed magnesium alloy via traditional hot-extrusion. J. Alloy. Compd. 2019, 810, 151967. [CrossRef]

43. Yu, H.; Xin, Y.; Wang, M.; Liu, Q. Hall-Petch relationship in Mg alloys: A review. J. Mater. Sci. Technol. 2018, 34, 248-256. [CrossRef]

44. Wang, H.Y.; Rong, J.; Liu, G.J.; Zha, M.; Wang, C.; Luo, D.; Jiang, Q.C. Effects of Zn on the microstructure and tensile properties of as-extruded Mg-8Al-2Sn alloy. Mater. Sci. Eng. A 2017, 698, 249-255. [CrossRef]

45. Gypen, L.A.; Deruyttere, A. Multi-component intrinsic solid solution softening and hardening. J. Less-Common Met. 1977, 56, 91-101. [CrossRef]

46. Toda-Caraballo, I.; Galindo-Nava, E.I.; Rivera-Díaz-del-Castillo, P.E.J. Understanding the factors influencing yield strength on Mg alloys. Acta Mater. 2014, 75, 287-296. [CrossRef] 
47. Yang, Q.; Jiang, B.; Tian, Y.; Liu, W.; Pan, F. A tilted weak texture processed by an asymmetric extrusion for magnesium alloy sheets. Mater. Lett. 2013, 100, 29-31. [CrossRef]

48. Zhang, J.; Guo, Z.X.; Pan, F.; Li, Z.; Luo, X. Effect of composition on the microstructure and mechanical properties of Mg-Zn-Al alloys. Mater. Sci. Eng. A 2007, 456, 43-51. [CrossRef] 